\title{
An Evaluation of Brazilian Ports for Corn Export Using Multicriteria Analysis
}

\author{
Aguinaldo Eduardo de Souza ${ }^{1,2}[0000-0001-6100-752 X]$, João José Giardulli \\ Junior $^{1[0000-0002-4860-2129]}$, João Gilberto Mendes dos \\ Reis $^{1,3[0000-0001-6409-2299]}$, Ataide Pereira Cardoso \\ Junior ${ }^{10000-0001-7754-0513]}$, Paula Ferreira da Cruz \\ Correia $^{1[0000-0003-1648-0398]}$, Ricardo Zandonadi \\ Schimidt ${ }^{1[0000-0002-9915-2519]}$, José Benedito Sacomano 1[0000-0002-4877-3139], \\ and Márcia Terra da Silva ${ }^{10000-0002-5314-4978]}$ \\ 1 Paulista University - UNIP, PPGEP, São Paulo, Brazil \\ 2 UNIBR, São Vicente, Brazil \\ 3 UFGD, PPGA, Dourados, Brazil
}

\begin{abstract}
Brazilian corn production has an expressive participation in world trade stage. Agribusiness has been growing and gaining an important position for economy in Brazil. The Brazilian corn harvest for 2017-2018 was 82 million tons, placing Brazil as the third largest global producer behind China and the United States. This study compares four south and southeast Brazilian corn exportation ports according to their operations, infrastructure and geographic position. A multicriteria decision tree was established and, with the analytical hierarchy process (AHP) tool, an informational database, and considering expert opinions about the gathered data, we were able to determine which ports are the better choices for corn exportation. Surprisingly, Rio Grande took a better place than Paranaguá's port. Its operations and infrastructure nodes have the same weight in terms of decision making. However, a ports geographical position has a very weak decision-make importance. Furthermore, Rio Grande is almost three times better than Paranaguá in Water Depth and this made Rio Grande beat Paranaguá from an infrastructure point of view. So, the operations node was the point to pay attention to, and this is the main reason for Rio Grande's position.
\end{abstract}

Keywords: Analytic Hierarquy Process - Port logistics · Agricultural Commodities, Hinterland.

\section{Introduction}

Agribusiness plays a prominent role in the Brazilian economy. New technologies for planting, expansion of planted areas, and increased productivity have allowed Brazil greater participation in global grain production [1]. In the 2017-2018 year crop, Brazil corn production, for instance, was 82 million tons, placing Brazil as the third largest global producer behind China and the United States, which produce 259 and 371 million tons, respectively. 
The port platforms are strategic for Brazilian corn exports. The practice of how the port is integrated into the process and its ability to generate value for the logistics chain are decisive factors for Brazil's competitiveness in the international market $[2,3,4,5,6,7,8]$.

The aim of this article is to compare the main ports for Brazilian corn exportation regarding their operations, infrastructure, and geographical position. To this end, we establish a decision tree and by using the analytical hierarchy process (AHP), informational databases, and specialist opinions we could conclude that operations and infrastructure quality have the same impact in decision making.

The article as divided as follows: After this introduction, a methodology is detailed, while the results and discussion section present the paper's findings, and the conclusion highlights the most interesting results.

\section{Methodology}

The methodology of this work consists of a comparison of four Brazilian ports that export corn: Santos, Paranaguá, Rio Grande, and São Francisco do Sul, which are responsible for the disposal of corn exports from the Central-South macro-region (amounting to 71 million tons for the 2017-2018 harvest) [1].

To compare these corridors, we based on the considerations made by three operations managers of the main corn handling ports in Brazil, Santos and Paranaguá respectively [9], and we developed a decision four considering three areas: port infrastructure, port operations, and port geography. For each criterion was created several sub-criterions, Figure 1.

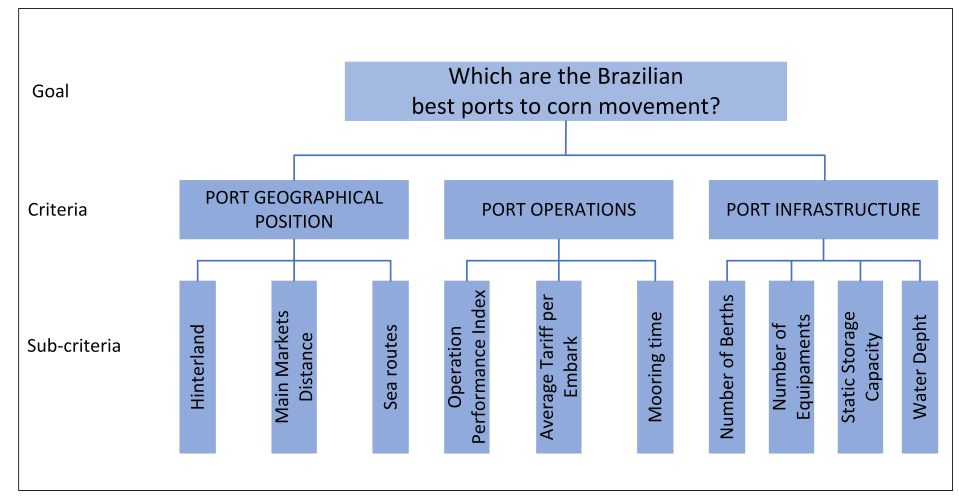

Fig. 1: Decision Tree

To solve the decision tree and identify which was the main port to export corn we used AHP for the decision-making process. 
The AHP method was developed by Tomas L. Saaty, being a multicriteria method more widely used and known in support of decision making, with problems with multiple criteria [10].

The criteria and sub-criteria are compared using an importance scale numbered between 1 and 9, where 1 indicates equivalent importance and 9 extreme importance. After that AHP converts the comparisons into fractions and the weight of each in the decision model is established [11].

Once the comparisons and relative weights between the criteria to be evaluated have been established, the numerical probability of each of the alternatives is calculated. Thus, it is possible to determine the probability that the alternative has met the established objective [12]. The participation of specialists in the judgment of any particular theme is fundamental for the construction of the decision tree in AHP [13]. This work specialists judged the comparisons considering the data provided $[14,15,16,17,18,19,20,21,9]$.

\section{Results and Discussion}

The Figure 2 presented the main results.

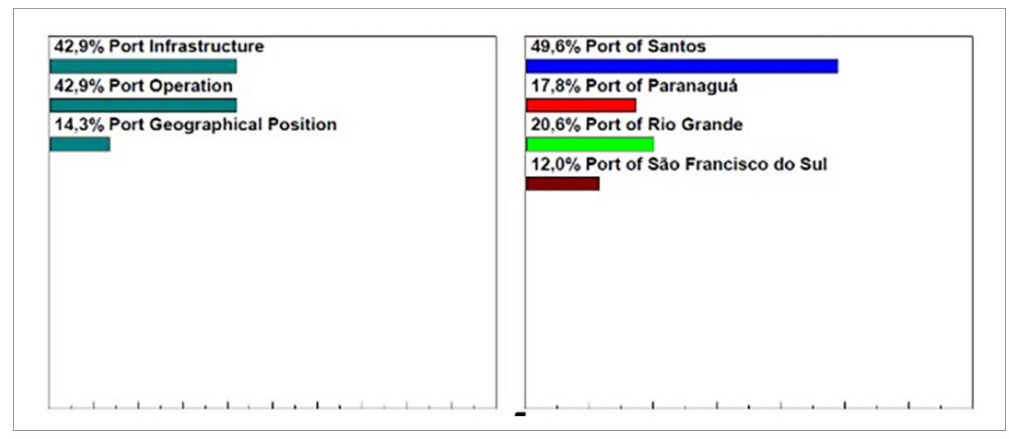

Fig. 2: General Result

As shown in Fig 1, the overall results point out that the port of Santos was the best choice for corn movement. This result is not surprising considering that Santos is the most important port in Latin America and responsible moving 67\% of Brazilian GDP [7]. The same thing is true of São Francisco do Sul, which does not have good infrastructure and has difficult access.

The result that deserves a look is the ports of Paranaguá and Rio Grande. Both of these ports show similar results for port infrastructure. Nonetheless, Rio Grande's port operations are better than Paranaguá's. This latter reason has vaulted Rio Grande's position over Paranaguá, as Figure 3 shows.

Also depicted in Figure 3, another aspect that must be strongly considered is the dynamic sensitivity of nodes, port infrastructure, and port operations, 


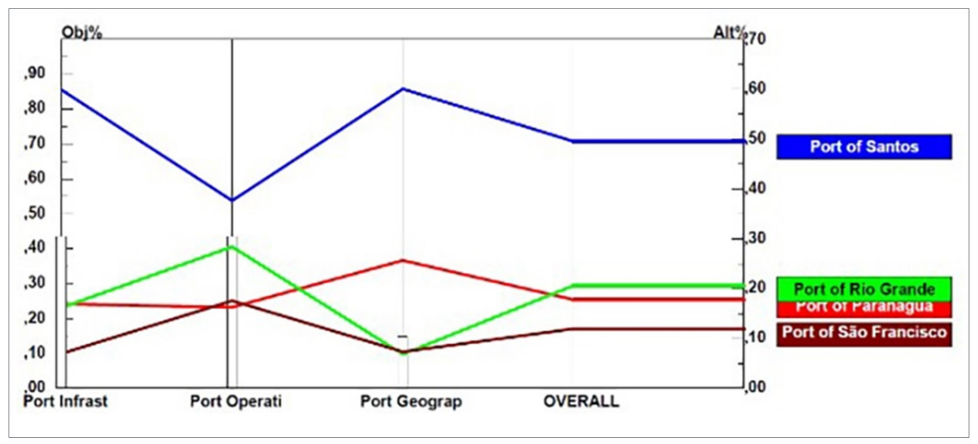

Fig. 3: Performance Sensitivity Nodes by Criteria

which have the same sensitivity. However, a port's geographical position, where the port of Santos has the highest performance of all, and the port of Paranaguá is much better than that of Rio Grande, which has the weakest sensitivity.

One striking result indicates the ports geography has low influence on shipment movements going to Brazilian ports. One of main the reasons could be that any distance under $2,000 \mathrm{~km}$ between ports does not affect route decisions if shipments are traveling for more than $10,000 \mathrm{~km}$. At the same time, there is no difference between port operations and port infrastructure in terms of decision making. Both have the same impact on corn movement decisions.

Once port operations and port infrastructure were considered to be the main criteria for decision making, we analyzed the sub-criteria in detail regarding just Paranaguá and Rio Grande once Santos was seen as the best option. Figure 4 presents sub-criteria for port operations.

Both Paranaguá and Rio Grande have almost the same score for the infrastructure node. Depicted in Figure 4, we can see the four topics considered in analysis and their sensitivities: static storage capacity (0.381), water depth (0.335), number of berths (0.187) and amount of equipment (0.097). Rio Grande is better than Paranaguá only in terms of water depth, almost three times better. It was enough to tie Rio Grande and Paranaguá for this node.

\begin{tabular}{|l|}
\hline \multicolumn{1}{|c|}{ Priorities with respect to: } \\
Which are the Brazilian Best Ports to corn movement? \\
>Port Infrastructure \\
Static Storage Capacity \\
Water Depth \\
Number of Ber ths \\
Number of Equipaments \\
Inconsistency = $\mathbf{0 , 0 4}$ \\
$\quad$ with 0 missing judgments.
\end{tabular}

Fig. 4: Port Infrastructure 
Both Paranaguá and Rio Grande have almost the same score for the infrastructure node. Depicted in Figure 4, we can see the four topics considered in analysis and their sensitivities: static storage capacity (0.381), water depth (0.335), number of berths (0.187) and amount of equipment (0.097). Rio Grande is better than Paranaguá only in terms of water depth, almost three times better. It was enough to tie Rio Grande and Paranaguá for this node. Figure 5 presents the results for Port Operation criteria.

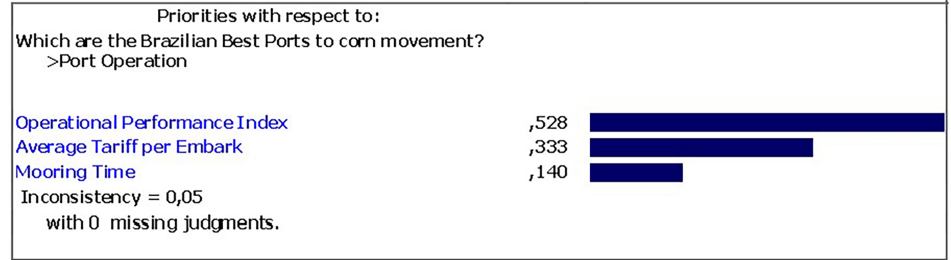

Fig. 5: Port Operation

Eventually, as can been seen in Figure 5, in port operations there are three sensitive topics, too: mooring time (0.140), average tariff per embarkation (0.333) and operational performance index (0.528). The port of Paranaguá was the worse choice in two of the three parameters. Paranaguá was better than Rio Grande only in its operational performance index.

\section{Conclusions and Outlook}

Regarding our results, we confirm that port of Santos is the main port for corn export due to having better port operations and infrastructure, despite its higher costs.

The port of São Francisco do Sul is of interest in terms of cost. However, its poor infrastructure and operations placed it last among the four options.

Nonetheless, considering the ports of Paranaguá and Rio Grande an unexpected situation occurred. The decision tree showed that the latter is a better choice than the former despite the longer distance to production areas.

Analyzing dynamic sensitivity for port infrastructure and port operation nodes (i.e., both being $42.9 \%$ ) and port geographical position (14.3\%), where the port of Paranaguá has a great advantage over Rio Grande (which has just $14.3 \%$ of dynamic sensitivity) we concluded that the port of Paranaguá urgently needs to improve its operations to avoid grain shipments migrating to Port of Rio Grande.

This study was financed in part by the Coordenacão de Aperfeicoamento de Pessoal de Nível Superior - Brasil (CAPES) - Finance Code 001. 


\section{References}

1. Companhia Nacional de Abastecimento: https://www.conab.gov.br/info-agro/ safras/serie-historica-das-safras

2. Marlow, P.B., Casaca, A.C.P.: Measuring lean ports performance. International journal of transport management 1(4), 189-202 (2003)

3. Dubke, A.F.: Specialized Terminals Location Model: A Case Study as Applied to Exportation Corridors of Soya. Ph.D. thesis, Pontifícia Universidade Católica do Rio De Janeiro - PUC-RIO (2007)

4. Chopra, S., Meindl, P.: Supply chain management: strategy, planning, and operation. Pearson, Boston, 5th ed edn. (2013), oCLC: ocn755904451

5. Brazilian Administrative Council for Economic Defense: (2013), http://www . cade. gov.br/noticias/dee-analisa-mercado-de-portos-brasileiro

6. Carvalho, A.X.Y., Coutinho, P.C., Oliveira, A.R.d., Britto, P.A.P.d., Lustosa, P.R.B.: Modelando o processo de seleção dos portos para movimentação das cargas no comércio exterior brasileiro. Instituto de Pesquisa Econômica Aplicada 2093 (2015)

7. Hilsdorf, W.d.C., Neto, N., Souza, M.d., Hilsdorf, W.d.C., Neto, N., Souza, M.d.: Port of Santos: prospection on the causes of access difficulties. Gestão \& Produção 23(1), 219-231 (2016)

8. Celio, A., Pozzoli, S.: Performance measurement in Port Authority: an exploratory study 3(3), 52-58 (2018)

9. Agency, B.N.W.T.: Port Handling Yearbook. Tech. rep., Braslia, DF (2019), http: //web.antaq.gov.br/Anuario/

10. Maleti, D., Maleti, M., Lovreni, V., Al-Najjar, B., Gomiek, B.: An Application of Analytic Hierarchy Process (AHP) and Sensitivity Analysis for Maintenance Policy Selection. Organizacija 47(3), 177-188 (2014)

11. Saaty, T.L.: Extending the Measurement of Tangibles to Intangibles. nternational Journal of Information Technology \& Decision Making 48(1), 7-27 (2009)

12. Wollmann, D.: Analytic Hierachy Process suportando a avaliao por pares. Revista Dilogo Educacional 17(52), 503 (Jun 2017)

13. Reis, J.G.M., Vendrametto, O., Naas, I.A., Costabile, L.T., Machado, S.T.: Avaliação das Estratégias de Comercializao do Milho em MS Aplicando o Analytic Hierarchy Process (AHP). Revista de Economia e Sociologia Rural 54(1), 131-146 (2016)

14. Administração dos Portos de Paranaguá e Antonina: (2019), http://www. portosdoparana.pr.gov.br/

15. Brazilian Institute of Geography and Statistics: https://www . ibge.gov.br/geociencias-novoportal/organizacao-do-territorio/ estrutura-territorial.html

16. Menegazzo, L., Petterini, F., Menegazzo, L., Petterini, F.: Maiores Navios no Mundo, mais um Desafio no Brasil: uma análise do Programa Nacional de Dragagem. Estudos Econômicos 48(1), 175-209 (2018)

17. Porto de São Francisco do Sul: https://www.apsfs.sc.gov.br/

18. Porto do Rio Grande: (2019), http://forum.al.rs.gov.br/wp/wp-content/ uploads/2015/07/DARCI_TARTARI-Porto\%20de\%20RG.pdf

19. Portworld Distance: http://www.portworld.com/map

20. Sea-Distances.org: https://sea-distances.org/

21. of the State of São Paulo, D.C.: http://www.portodesantos.com.br/ outros-links/calado-maximo-operacional/ 